\title{
Protective Effect of N-Acetylcysteine on The Kidney and Liver Pathology Induced by NMDA Receptor Antagonist Mk-801 in Mice
}

\author{
Murat Sırrı AKOSMAN ${ }^{*}$, Hasan Hüseyin DEMİREL², Ruhi TURKMEN³ \\ ${ }^{1}$ Department of Anatomy, Faculty of Veterinary Medicine, University of Afyon Kocatepe, Afyonkarahisar, Turkey \\ ${ }^{2}$ Bayat Vocational School, University of Afyon Kocatepe, Afyonkarabisar, Turkey \\ ${ }^{3}$ Department of Pharmacology and Toxicology, Faculty of Veterinary Medicine, University of Afyon Kocatepe, Afyonkarahisar, Turkey
}

\begin{abstract}
The glutamatergic system and its receptor N-methyl-D-aspartate (NMDA) is an important synapse mechanism in the nervous system. The MK-801 is the blocker of this receptor and according to the literature, the sub-chronic administration of $1 \mathrm{mg} / \mathrm{kg}$ MK-801 resulted in schizophrenia-like symptoms and degeneration in the mice brain. The aim of the present study was to observe whether this dose of MK-801 has any pathological effect on the liver and kidney tissues and whether $\mathrm{N}$-acetylcysteine (NAC) was a protective effect. For this purpose, the $24 \mathrm{Balb} / \mathrm{C}$ male mice were divided into 4 groups, equally. The first group was the control and $0.9 \%$ saline $(10 \mathrm{mg} / \mathrm{kg}) \mathrm{was}$ intraperitoneally (i.p.) injected. The $1 \mathrm{mg} / \mathrm{kg}$ MK- 801 was i.p. administered to the second group. The third group was i.p. received $1 \mathrm{mg} / \mathrm{kg}$ MK-801, $100 \mathrm{mg} / \mathrm{kg} \mathrm{NAC}$ and finally the $100 \mathrm{mg} / \mathrm{kg}$ NAC i.p. injected to the fourth group. The drug administration was ended on the $14^{\text {th }}$ day. The kidney and the liver of the sacrificed mice were collected and routine histology procedure was applied. The histopathological changes in the organs and NAC's mostly protective effect were noticed after the observations. In conclusion, NAC has a partially but significantly protective effect against the MK-801 dependent histopathological changes on the kidney and liver tissues.
\end{abstract}

Keywords: Histopathology, Kidney, Liver, Mice, MK-801, N-acetylcysteine

\section{$* * *$ \\ Farelerde NMDA Reseptör Antagonisti Mk-801 ile Böbrek ve Karaciğerde Oluşan Patolojik Değişikliklere Karş1 N-Asetilsisteinin Koruyucu Etkisi}

\section{ÖZ}

Glutamaterjik sistem sinir sisteminde önemli bir sinaps mekanizmasıdır. N-metil-D-aspartat (NMDA) reseptörleri bu sistemin önemli bir parçasıdır. NMDA reseptörlerinin hipofonksiyonu farelerde kognitif ve motorik sorunlara sebep olmaktadır. MK-801 bu reseptörün oldukça önemli bir blokörüdür. $1 \mathrm{mg} / \mathrm{kg}$ MK-801'in sub-kronik uygulanması farelerde şizofreni benzeri semptomlara ve beyinde dejenerasyona sebep olmaktadır. Sunulan bu çalışmada MK-801'in 1mg/kg'llk sub-kronik uygulamasının farelerin böbrek ve karaciğerlerinde patolojik etkileri olup olmadığı ve N-asetilsisteinin'in (NAS) bu etkiler karşısında koruyucu etkisinin olup olmadığ1 araştırıldı. Bu amaçla 24 adet erkek Balb/C faresi alınarak dört eşit gruba bölündü. İlk grup kontrollerden oluştu ve bu gruba $\% 0,9$ fizyolojik tuzlu su $(10 \mathrm{mg} / \mathrm{kg})$ intraperitoneal (i.p.) yolla, ikinci gruba $1 \mathrm{mg} / \mathrm{kg}$ dozunda MK-801 i.p., üçüncü gruba $1 \mathrm{mg} / \mathrm{kg}$ MK-801 ile $100 \mathrm{mg} / \mathrm{kg}$ NAS birlikte i.p ve dördüncü gruba da $100 \mathrm{mg} / \mathrm{kg}$ NAS i.p. yolla verildi. İlaç uygulamalar1 14 gün boyunca sürdü. Sakrifiye edilen farelerin karaciğer ve böbrekleri alınarak bunlara rutin histoloji prosedürü uygulandı. İncelemelerden sonra organlarda histopatolojik değişkilikler ve NAS'ın genelde koruyucu etkisinin olduğu gözlendi. Sonuç olarak NAS'ın böbrek ve karaciğer üzerinde MK-801'le indüklenen histopatolojik değişikliklere karşı önemli bir koruyucu etkisinin olduğu ortaya kondu.

Anahtar Kelimeler: Böbrek, Fare, Histopatoloji, Karaciğer, MK-801, N-asetilsistein

To cite this article: Akosman M.S. Demirel H.H. Türkmen R. Protective Effect of N-Acetylcysteine on The Kidney and Liver Pathology Induced by Nmda Receptor Antagonist Mk-801 in Mice. Kocatepe Vet J. (2019) 12(3):258-263. 


\section{INTRODUCTION}

Glutamate is the main neurotransmitter and the glutamatergic system is the most important synapse system of the nervous system (IOM 2011, Vandogen 2009). NMDA receptors are important elements of the glutamatergic system and hypofunction of this receptor can cause cognitive and motor problems in human and animals (Javitt 2007, Kruk-Slomka et al. 2016, Xiu et al. 2014, 2015). The NMDA receptor antagonist MK-801 is the blocker and the neurotoxic antagonist of this receptor (Ozyurt et al. 2014, Xiu et al. 2014, 2015). According to the previous studies, the higher doses of the MK-801 give harm to the internal organs (Fix et al. 2000). In addition, the sub-chronic dose of the MK-801 $(1 \mathrm{mg} / \mathrm{kg})$ causes degenerations in the brain and revealed schizophrenia-like symptoms in the mice (Xiu et al. 2014, 2015). Recently, it was found out that the glutamatergic system transporters and receptors are placed in the several organs of the body such as kidney and liver (Hu et al. 2004). Within the kidney, NMDA receptors can be found in the cortex, medullary and renal proximal tubules (Dryer et al. 2015, Leung et al. 2008).

Low doses of MK-801 can be used therapeutically in kidney and liver degeneration. For example, the 0.5 $\mathrm{mg} / \mathrm{kg}$ of MK-801 administration during 28 days was mitigated the glomerular and tubular dysfunction in the ischemic and reperfused kidneys (Lin et al. 2015, Roshanravan et al. 2016). It was also ameliorated the kidney damage dependent on gentamicin use (Leung et al. 2004). Controversially, MK-801 causes some degeneration of the kidney because the kidneys reduce the glomerular filtration rate and increase the number of podocytes (Deng et al. 2002, 2009, Giardino et al. 2009, Hashimoto 2017). In addition, MK-801 has been shown to intensify the harmful effects of dexamethasone and to make morphological changes after individual applications (Sekita-Krzak et al. 2004). Information about the effects of MK-801 on the liver is limited in the literature. Previously, it was reported that MK-801 could be used as a preventive in acute liver failure (Cauli et al. 2008, Rodrigo et al. 2009).

The antioxidant NAC is the mostly known mucolytic agent and the paracetamol antidote (Deepmala et al. 2015). However, it is known that the NAC ameliorates the glomerular filtration rate, improves the kidney function and reduces the inflammation in the kidney (Nitescu et al. 2006). The NAC is also effective and prophylactic on liver disorders such as fatty liver and hepatotoxicity (Khoshbaten et al. 2010).

The aim of this study was to observe the harmful effects of sub-chronic administration of $1 \mathrm{mg} / \mathrm{kg}$
MK-801 and the protective effect of NAC on the kidney and liver of mice.

\section{MATERIAL and METHODS}

Animals

This study was conducted on 24 male Balb/c mice (obtained from the Kobay a.ş.) under the permission of the Ethical Committee of Experimental Animals, Afyon Kocatepe University, AKUHADYEK-189-17. The animals were kept at the Experimental Animal Research Centre of Afyonkarahisar. The room temperature was adjusted to $22 \pm 2{ }^{\circ} \mathrm{C}$ with a $12 / 12 \mathrm{~h}$ light/dark cycle and ad libitum feeding.

\section{Groups and dosages}

The 24 mice were equally divided into 4 groups. The Group I was the control and $0.9 \%$ saline $(10 \mathrm{ml} / \mathrm{kg})$ was intraperitoneally (i.p.) injected due to MK-801 (Sigma, St. Louis, MO, USA) dissolved in the saline. The MK-801 $(1 \mathrm{mg} / \mathrm{kg})$ i.p. injected to Group II. The Group III was i.p. received $1 \mathrm{mg} / \mathrm{kg}$ MK-801 and $100 \mathrm{mg} / \mathrm{kg} \mathrm{NAC}$ and the fourth group was i.p. received $100 \mathrm{mg} / \mathrm{kg}$ NAC. All injections were performed for 14 days. In the third group, NAC was injected in the morning and MK-801 was injected in the afternoon.

\section{Histological tissue processing}

At the end of the trial, all the mice were sacrificed and the necropsy was formed. The kidney and liver were collected and fixed by 10\% formalin during two weeks and then embedded into paraffin. The tissues were trimmed into $5 \mu \mathrm{m}$ thickness, consecutively. All the slides were stained with hematoxylin-eosin.

\section{Tissue evaluation}

The glomerular atrophy was evaluated on the computer loaded M-Shot software attached to the Olympus microscope with M-Shot $14 \mathrm{mp}$ camera. Semiquantitative scoring of the liver and kidney was done according to previous research (Gibson-Corley et al. 2013).

\section{Statistical analysis}

The data about the glomerular shrinkage was estimated as means and standard deviations and analysed using one-way analysis of variance (ANOVA) followed by Duncan posthoc test on the SPSS 16.0 software computer programme. A difference in the mean values of $\mathrm{P}<0.05$ was considered to be significant.

\section{RESULTS}

The glomerular atrophy in the kidney and histopathological changes both in the kidney and liver tissue was observed after the sub-chronic administration of $1 \mathrm{mg} / \mathrm{kg}$ MK-801 (Table 1, 2 and Figure 1, 2). Besides, the protective role of the NAC was expressed in the tables and figures. 

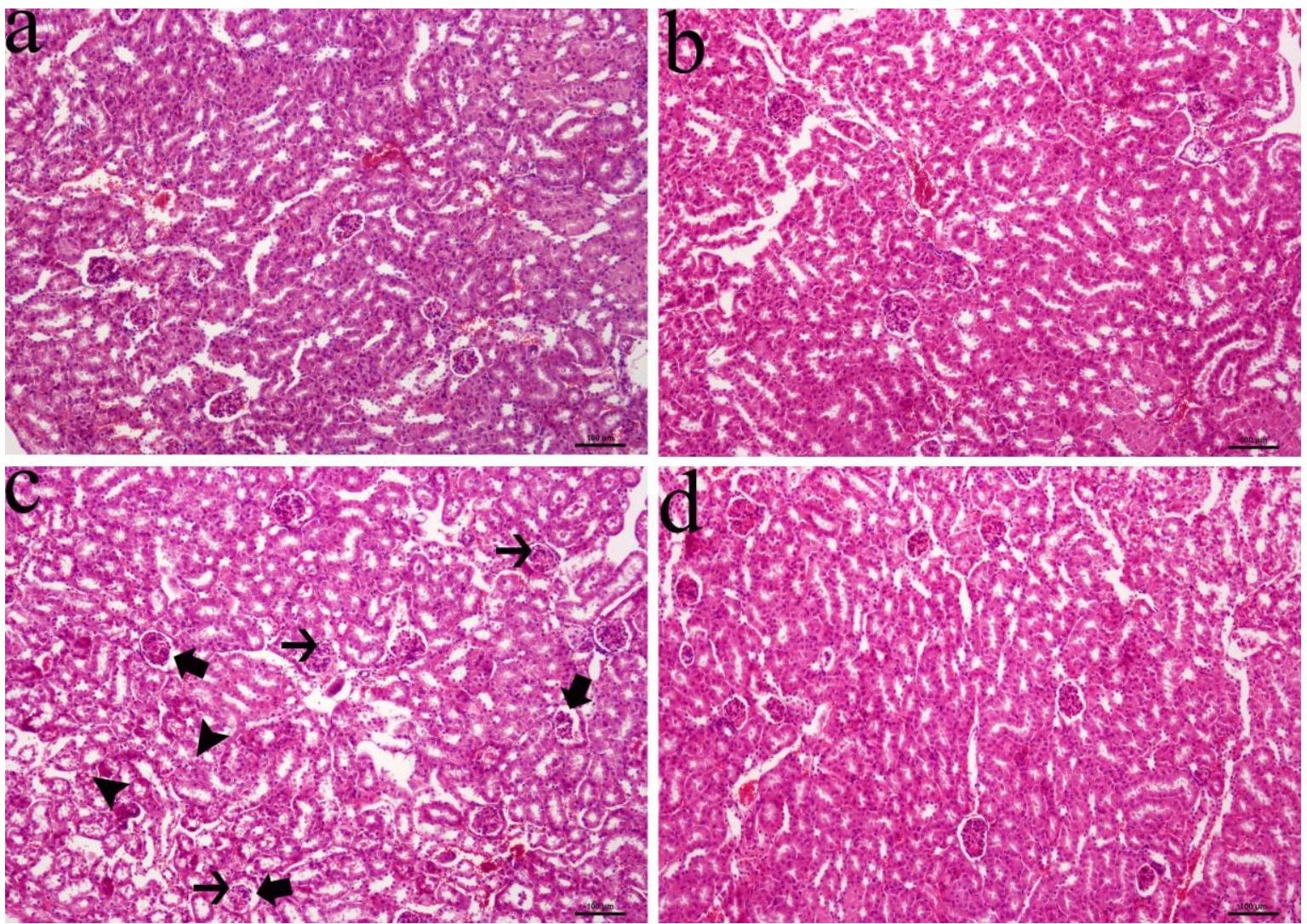

Figure 1. a. Control group, b. NAC group, c. MK-801 group; thick arrow: expansion in the bowmanspace, thin arrow: vacuolar degeneration in the glomerulus, arrowhead: degenerative and necrobiotic changes in the tubular epithelial cells d. MK-801+NAC group
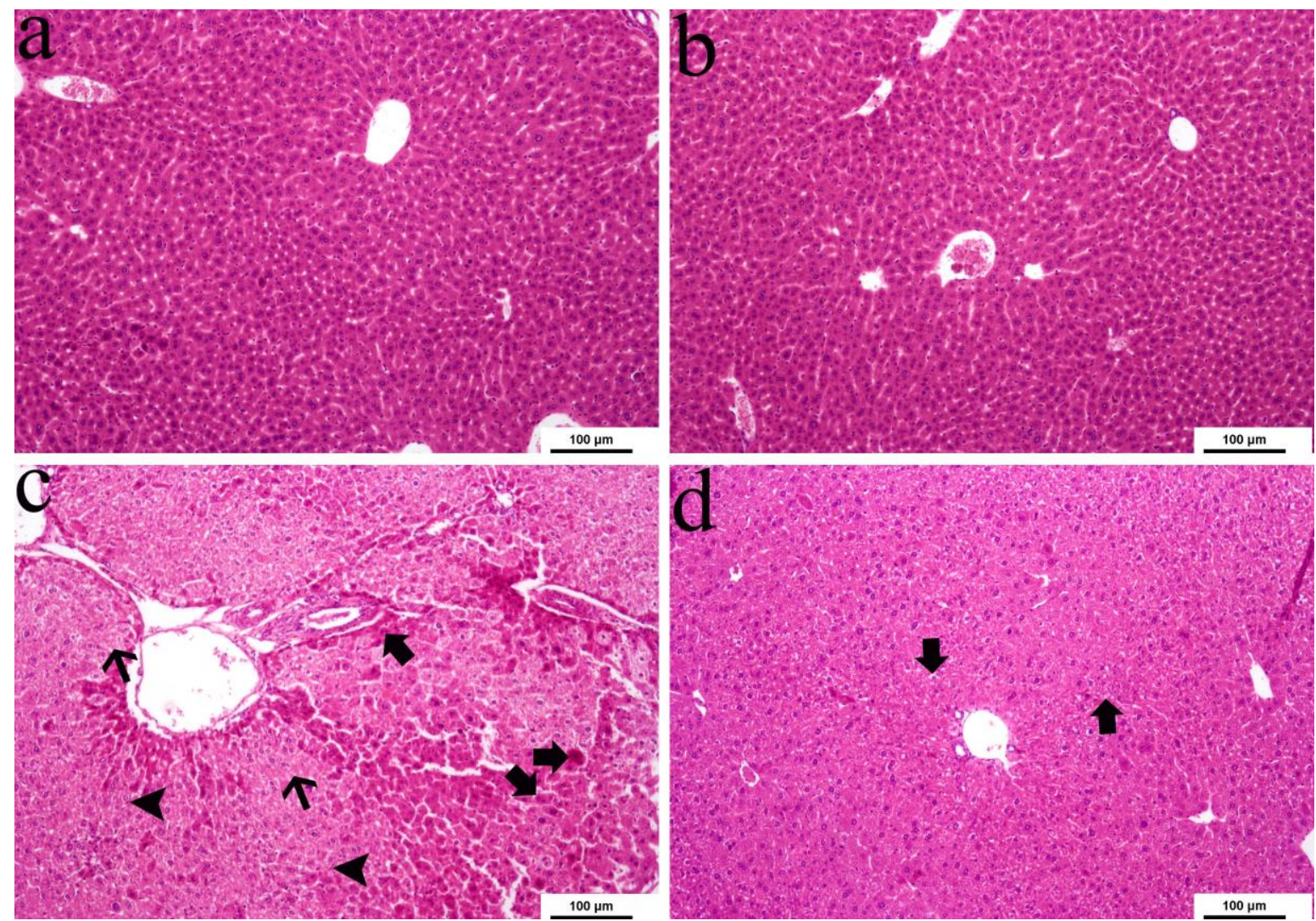

Figure 2. a. Control group, b. NAC group, c. MK-801 group: Thick arrow: Double-nuclei hepatocytes in the periportal area, Thin arrow: multifocal coagulation necrosis, Arrowhead: Kuppfer cell activation, d. MK-801+NAC group: Thick arrow: Vacuolar degeneration area around the central vein 
Table 1. Measurement of the glomerulus diameter.

\begin{tabular}{ll}
\hline Groups & The mean glomerulus diameter \\
\hline Control & $112 \pm 5^{\mathrm{a}}$ \\
MK-801 & $102 \pm 8^{\mathrm{b}}$ \\
$\mathrm{NAC}+\mathrm{MK}-801$ & $107 \pm 7^{\mathrm{ab}}$ \\
$\mathrm{NAC}$ & $110 \pm 3^{\mathrm{a}}$ \\
P value & 0,03
\end{tabular}

Values are the mean \pm S.D, $n=6$.

a,b: In the same column values with different letters show statistically significant differences in

"the mean glomerulus diameter" $(\mathrm{P}<0,05)$

Table 2. Histopathological observation of the liver and kidney

\begin{tabular}{|c|c|c|c|c|c|}
\hline Tissue & Histo-pathological findings & Control & NAC & MK-801 & MK-801 + NAC \\
\hline \multirow[t]{4}{*}{ Liver } & Multifocal coagulation necrosis & $-(7 / 7)$ & $-(7 / 7)$ & $\begin{array}{l}+(4 / 7) \\
++(1 / 7) \\
+++(2 / 7)\end{array}$ & $-(7 / 7)$ \\
\hline & Kuppfer cell activation & $-(7 / 7)$ & $-(7 / 7)$ & $\begin{array}{l}-(3 / 7) \\
+(1 / 7) \\
++(3 / 7)\end{array}$ & $\begin{array}{l}-(5 / 7) \\
+(2 / 7)\end{array}$ \\
\hline & $\begin{array}{l}\text { Double-nuclei hepatocytes in the } \\
\text { periportal area }\end{array}$ & $-(7 / 7)$ & $-(7 / 7)$ & $\begin{array}{l}+(5 / 7) \\
++(2 / 7)\end{array}$ & $-(7 / 7)$ \\
\hline & $\begin{array}{l}\text { Vacuolar degeneration around the } \\
\text { central veins }\end{array}$ & $-(7 / 7)$ & $-(7 / 7)$ & $+(7 / 7)$ & $\begin{array}{l}-(6 / 7) \\
+(1 / 7)\end{array}$ \\
\hline \multirow[t]{3}{*}{ Kidney } & $\begin{array}{l}\text { Vacuolar degeneration in the } \\
\text { glomerulus }\end{array}$ & $-(7 / 7)$ & $-(7 / 7)$ & $\begin{array}{l}-(2 / 7) \\
+(3 / 7) \\
++(2 / 7)\end{array}$ & $-(7 / 7)$ \\
\hline & Expansion in the bowman-space & $-(7 / 7)$ & $-(7 / 7)$ & $\begin{array}{l}+(3 / 7) \\
++(4 / 7)\end{array}$ & $\begin{array}{l}-(6 / 7) \\
+(1 / 7)\end{array}$ \\
\hline & $\begin{array}{l}\text { Degenerative and necrobiotic } \\
\text { changes in the tubular epithelial cells }\end{array}$ & $-(7 / 7)$ & $-(7 / 7)$ & $\begin{array}{l}+(4 / 7) \\
++(2 / 7) \\
+++(1 / 7)\end{array}$ & $-(7 / 7)$ \\
\hline
\end{tabular}

-:No lesions, +Mild, ++:Moderate, $+++:$ Severe

\section{DISCUSSION}

The glutamatergic system and its units are the important neurotransmitter mechanism in the brain (IOM 2011) and the NMDA receptors are one of the most important pieces of this system. The recent findings revealed that the hypo function of the NMDA receptors occurs cognitive and motoric problems (Xiu et al. 2014, 2015). The MK-801 is the blocker and toxic antagonist of this receptor and it's $1 \mathrm{mg} / \mathrm{kg}$ sub-chronic dose administration during 14 days to the mice resulted in schizophrenia-like symptoms (Xiu et al. 2014, 2015). Besides the NMDA receptors are placed in the brain, it was discovered that they also expressed in the liver and kidney.
However, there is limited knowledge in the literature about the effect of this dose on the liver and kidney. In the previous studies, it was reported that $0.3 \mathrm{mg} / \mathrm{kg}$ of MK-801 causes slight narrowing in the urinary space of the nephrons and its combination with the dexamethasone additionally to the hyperemia in the kidney, dilated the spaces in the nephrons (SekitaKrzak et al. 2004). Moreover, in another research, the MK-801 administration was constructed the kidney veins, reduced the glomerular filtration rate and produced abundant podocyte skeleton (Deng et al. 2002, 2009, Giardino et al. 2009, Hashimoto 2017). Besides, in this study, the sub-chronic administration of the MK-801 caused vacuolar degeneration in the glomerulus, expansion in the bowman-space, degenerative and necrobiotic changes in the tubular epithelial cells where the NMDA receptors 
expression areas. The NAC application is protected against these harmful effects on the kidney.

In the literature, the effect of the MK-801 on the liver was very limited. In the previous studies, the MK-801 has treated the ALF syndrome (Cauli et al. 2008, Rodrigo et al. 2009). However, due to the side effects of MK-801 such as the cognitive and motoric problems, it's not suitable in the clinical practice. Additionally to this, the findings of the present study revealed that the sub-chronic administration of the MK-801 causes multifocal coagulation necrosis, kuppfer cell activation, hepatocytes with doublenuclei in the periportal area and vacuolar degeneration around the central veins. The NAC administration has protected the tissue on a large scale.

In conclusion, in the present study, the harmful effects of the sub-chronic administration of MK-801 on the kidney and liver and the protective effect of the NAC against this administration were revealed. NAC inhibits most of the destructive effect of MK801 and it is particularly important to prevent degenerative and necrobiotic changes of tubular epithelial cells due to the expression domains of NMDA receptors in the kidney.

\section{ACKNOWLEDGEMENT}

This study was supported by the Afyon Kocatepe University Scientific Research Project Coordination Unit (17.Kariyer.45).

\section{REFERENCES}

Cauli O, Rodrigo R, Boix J, Piedrafita B, Agusti A, Felipo V. Acute liver failure-induced death of rats is delayed or prevented by blocking NMDA receptors in brain. Am J Physiol Gastrointest Liver Physiol. 2008;295(3):G503-11.

Deepmala J, Slattery N, Kumar L, Delhey M, Berk O, Dean C, Spielholz RF. Clinical trials of $\mathrm{N}$-acetylcysteine in psychiatry and neurology: a systematic review. Neurosci. Biobehav. Rev. 2015;55:294-321

Deng A, Valdivielso JM, Munger KA, Blantz RC, Thomson SC. Vasodilatory N-methyl-D-aspartate receptors are constitutively expressed in rat kidney. J Am Soc Nephrol. 2002;13(5):1381-4.

Deng A, Thomson SC. Renal NMDA receptors independently stimulate proximal reabsorption and glomerular filtration. Am J Physiol Renal Physiol. 2009;296(5):F976-82.

Dryer SE. Glutamate receptors in the kidney. Nephrology Dialysis Transplantation, 2015;30(10):1630-1638.

Fix AS, Stitzel SR, Ridder GM, Switzer RC. MK-801 neurotoxicity in cupric silver-stained sections: lesion reconstruction by 3-dimensional computer image analysis. Toxicol Pathol. 2000;28(1):84-90.

Giardino L, Armelloni S, Corbelli A, Mattinzoli D, Zennaro C, Guerrot D, Tourrel F, Ikehata M, Li M, Berra S, Carraro M, Messa P, Rastaldi MP. Podocyte glutamatergic signaling contributes to the function of the glomerular filtration barrier. J Am Soc Nephrol. 2009;20(9):1929-40.

Gibson-Corley KN, Olivier AK, Meyerholz DK. Principles for valid histopathological scoring in research. Vet Pathol. 2013;50(6):1007-15.

Hashimoto K: The NMDA receptors. Humana Press. pp. 62-64, 2017.

Hu JH, Yang N, Ma YH, Jiang J, Zhang JF, Fei J, Guo LH. Identification of glutamate transporters and receptors in mouse testis. Acta Pharmacol Sin. 2004;25:366-371.

IOM (Institute of Medicine). Glutamate-related biomarkers in drug development for disorders of the nervous system: A workshop summary. Washington, DC: The National Academies Press. pp: 5-8. 2011.

Javitt DC. Glutamate and schizophrenia: phencyclidine, Nmethyl-D-aspartate receptors, and dopamine-glutamate interactions. Int Rev Neurobiol. 2007;78:69-108.

Khoshbaten M1, Aliasgarzadeh A, Masnadi K, Tarzamani MK, Farhang S, Babaei H, Kiani J, Zaare M, Najafipoor F. N-acetylcysteine improves liver function in patients with non-alcoholic Fatty liver disease. Hepat Mon. 2010;10(1):12-6.

Kruk-Slomka M, Budzynska B, Slomka T, Banaszkiewicz I, Biala G. The influence of the CB1 receptor ligands on the schizophrenia-like effects in mice induced by MK801. Neurotox Res. 2016;30:658-676.

Leung JC, Marphis T, Craver RD, Silverstein DM. Altered NMDA receptor expression in renal toxicity: Protection with a receptor antagonist. Kidney Int. 2004;66(1):167176

Leung JC, Ragland N, Marphis T, Silverstein DM. NMDA agonists and antagonists induce renal culture cell toxicity. Med Chem. 2008;4(6):565-571.

Lin CS, Hung SF, Huang HS, Ma MC. Blockade of the NMethyl-D-Aspartate glutamate receptor ameliorates lipopolysaccharide- induced renal insufficiency. PLoS ONE. 2015;10(7):1-18.

Nitescu N, Ricksten SE, Marcussen N, Haraldsson B, Nilsson U, Basu S, Guron G. N-acetylcysteine attenuates kidney injury in rats subjected to renal ischaemia-reperfusion. Nephrol Dial Transplant. 2006;21:1240-1247.

Ozyurt H, Ozyurt B, Sarsilmaz M, Kus I, Songur A, Akyol O. Potential role of some oxidant/antioxidant status parameters in prefrontal cortex of rat brain in an experimental psychosis model and the protective effects of melatonin. Eur Rev Med Pharmacol Sci. 2014;18(15):2137-2144.

Rodrigo R, Cauli O, Boix J, ElMlili N, Agusti A, Felipo V. Role of NMDA receptors in acute liver failure and ammonia toxicity: therapeutical implications. Neurochem Int. 2009;55(1-3):113-8.

Roshanravan H, Kim EY, Dryer SE. NMDA Receptors as Potential Therapeutic Targets in Diabetic Nephropathy: Increased Renal NMDA Receptor Subunit Expression in Akita Mice and Reduced Nephropathy Following Sustained Treatment With Memantine or MK-801. Diabetes. 2016;65(10):3139-50.

Sekita-Krzak J, Visconti J, Wójtowicz Z, Zebrowska-Lupina I, Ossowska G, Klenk-Majewska B. Histological examination of the kidney after experimental administration of MK-801 and dexamethasone. Ann Univ Mariae Curie Sklodowska Med. 2004;59(2):70-4. 
Vandongen MA. Biology of the NMDA receptor. CRC Press Taylor and Francis Group. USA. pp:1-8. 2009.

Xiu Y, Kong XR, Zhang L, Qiu X, Chao FL, Peng C, Gao Y, Huang CX, Wang SR, Tang Y. White matter injuries induced by MK-801 in a mouse model of schizophrenia based on NMDA antagonism. Anat Rec (Hoboken). 2014;297(8):1498-507.

Xiu Y, Kong XR, Zhang L, Qiu X, Gao Y, Huang CX, Chao FL, Wang SR, Tang Y. The myelinated fiber loss in the corpus callosum of mouse model of schizophrenia induced by MK-801. J Psychiatr Res. 2015;63:132-40. 